\title{
Association of Rainfall and Stability Index with Lightning Parameter over the Indo-Gangetic Plains
}

\author{
M. I. R. Tinmaker, M. Y. Aslam, D. M. Chate* \\ Indian Institute of Tropical Meteorology, Pune, India \\ Email: *chate@tropmet.res.in
}

How to cite this paper: Tinmaker, M.I.R., Aslam, M.Y. and Chate, D.M. (2017) Association of Rainfall and Stability Index with Lightning Parameter over the Indo-Gangetic Plains. American Journal of Climate Change, 6, 443-454.

https://doi.org/10.4236/ajcc.2017.63023

Received: July 24, 2017

Accepted: August 8, 2017

Published: August 11, 2017

Copyright $\odot 2017$ by authors and Scientific Research Publishing Inc. This work is licensed under the Creative Commons Attribution International License (CC BY 4.0).

http://creativecommons.org/licenses/by/4.0/

(c) (i) Open Access

\begin{abstract}
The Lightning Imaging Sensor (LIS) based satellite lightning grid data for 10 year period (1998-2007) were used to study the association of rainfall and stability index with lightning parameter over Indo-Gangetic plain (IGP) region. The spatial variation of flash rate density (FRD) is found to be $\left(40 \mathrm{fl} \cdot \mathrm{km}^{-2} \cdot \mathrm{yr}^{-1}\right)$ higher over northern region of IGP as compare to that of eastern IGP region. The annual variation of FRD exhibits bimodal distributions, while the precipitation rate shows unimodal distributions. The results show that the FRD peaked 2 months (premonsoon) in advance to the monsoon months where rainfall peak occurred due to environmental lapse rates more than $7.0^{\circ} \mathrm{C} / \mathrm{km}$ during pre-monsoon which is evident from the temperature profile for correlation coefficient between temperature $(700 \mathrm{mb})$ and FRD with coefficient of $0.70, p \leq 0.0001$ during pre-monsoon. The annual variation of lifted index show negative value over March to September due to intense insolation, convective available potential energy (CAPE) and also availability of moisture. The convective cloud transform into thundercloud with the development of mixed-phase (cloud water + ice) which subsequently produce the lightning. During monsoon, seasonal thermal heating diminishes and even on revival after break monsoon period, $\mathrm{K}$-index is found to be less as the orography does not allow the highly moist air of low temperature to reach to large height above freezing level. They can be referred as maritime clouds of intermediate height with moderate updraft and hence minimum lightning activity during the monsoon season. Lifted index are proved to be indicators of thunderstorm conditions. This is because that rising air parcel is much warmer than its surroundings and can accelerate rapidly and create severe thunderstorms.
\end{abstract}

\section{Keywords}

Flash Rate Density, Precipitation Rate, Lifted Index, K-Index 


\section{Introduction}

Lightning and precipitation have received a lot of attention in the scientific literature, not only because it is an impressive atmospheric phenomenon but also because it is associated with severe storms that may cause important damages to agriculture, electric power networks, property and life [1] [2] [3] [4] [5]. Stability indices are a measure of the atmospheric static stability. Their values are used to quickly assess the potential of the atmosphere to produce convection and consequently severe weather. LI indicates the likelihood of severe thunderstorms. Lifted index (LI) is a measure of upper level instability and takes into account elevated convection which tends to occur when upper level disturbances move across unstable equilibrium environment aloft. Negative LI indicates the possibility of convection. Values less than $-9^{\circ} \mathrm{C}$ reflect extreme instability. A value of LI between $0^{\circ} \mathrm{C}$ and $-2^{\circ} \mathrm{C}$ indicates a small chance of having a severe thunderstorm. Air mass thunderstorms can occur even when the LI is slightly positive [6] [7] [8]. K Index has been proved useful in indicating the probability of air mass thunderstorms. As the $\mathrm{K}$ Index increases, so does the probability of having an air mass thunderstorm. K Index takes into account three components which are important for convective instability: temperature lapse rate, lower tropospheric humidity and the vertical extent of the moist layer. Values of $\mathrm{K}$ Index lower than $15^{\circ} \mathrm{C}$ [9] indicate very small likelihood of thunderstorms, while $\mathrm{K}$ Index values higher than $35^{\circ} \mathrm{C}$ indicate high probability for the development of numerous and/ or severe thunderstorms.

Large body of literature is available for thunderstorm and lightning research [10]-[16]. Also, over the Indian region, attempts have been made to understand relation of thunderstorms to wet bulb temperature [17] [18] [19] [20], lightningrainfall relationship [21] and also, thunderstorm climatology [22]. The analysis of satellite data in this study focuses on the association of rainfall and stability index with lightning parameter over the hot spot region of Indo-Gangetic Plains.

\section{Data and Source Description}

The Lightning Imaging Sensor (LIS) is a satellite-borne instrument used to detect the lightning flashes occurring in the tropics [23] [24]. It is a National Aeronautics and Space Administration's (NASA) Earth Observing System (EOS) instrument on the Tropical Rainfall Measuring Mission (TRMM) Satellite. The LIS is designed with a higher sensitivity and spatial accuracy than the Optical Transient Detector (OTD). It detects lightning flash with storm-scale (spatial) resolution $(4$ to $7 \mathrm{~km})$ over a large region $(600 \times 600 \mathrm{~km})$ of the Earth's surface. LIS was launched on 28 November 1997 into low Earth orbit to circle the Earth at an altitude of $350 \mathrm{~km}$. The TRMM satellite was boosted from an average altitude of about $350 \mathrm{~km}$ before August 2001 to about $400 \mathrm{~km}$ after August 2001. The higher altitude (at an orbital inclination of $35^{\circ}$ ) gives a correspondingly larger field of view for each of the sensor pixels and swath and longer sampling duration that increases the total flash counts [25]. Lightning flash illuminates a cloud top area 
significantly larger than the field of view of an LIS pixel. Also, the LIS detection threshold settings were not changed after boost. Thus, there is no change in detection efficiency. The inclination of the orbit is $35^{\circ}$, which allows the LIS to observe the lightning activity in the tropical regions of the globe. It detects the lightning activity with detection efficiency of $90 \%$ with negligible regional bias [26] for flash with detection efficiency $93 \% \pm 4 \%$ and $73 \% \pm 11 \%$ during night and day respectively. LIS records both cloud-to-ground and intra-cloud lightning in terms of total flash count.

The present study involves LIS flash rate density data for a period of 10 years $(1998-2007)$ over the IGP domain $\left(21^{\circ}-32^{\circ} \mathrm{N}\right.$ and $\left.73^{\circ}-89^{\circ} \mathrm{E}\right)$ region as shown in Figure 1. The LIS flash count data were retrieved [27]. The monthly flash rate density is obtained from total lightning flash count and gridded with a spatial resolution of $0.5^{\circ} \times 0.5^{\circ}$ for a 10 -year period from 1998-2007. The monthly flash rate density $\left(\mathrm{Fl} \cdot \mathrm{Km}^{-2} \cdot \mathrm{Yr}^{-1}\right)$ over a year at each grid $\left(0.5^{\circ} \times 0.5^{\circ}\right)$ is calculated by dividing flash count with view time and grid and by multiplying with total seconds of a year. India Meteorological Department categorizes four seasons namely; pre-monsoon (March-May), monsoon (June-September), post-monsoon (October-November) and winter (December-February). Along with monthly flash rate density a 10year period (1998-2007), rainfall data for the same period and region are extracted from Climatic Data Centre of National Oceanic and Atmospheric Administration (NOAA). The data for LI and K-index for Patna in the IGP region for the same period were obtained from University of Wyoming (http://weather.uwyo.edu/upperair/).

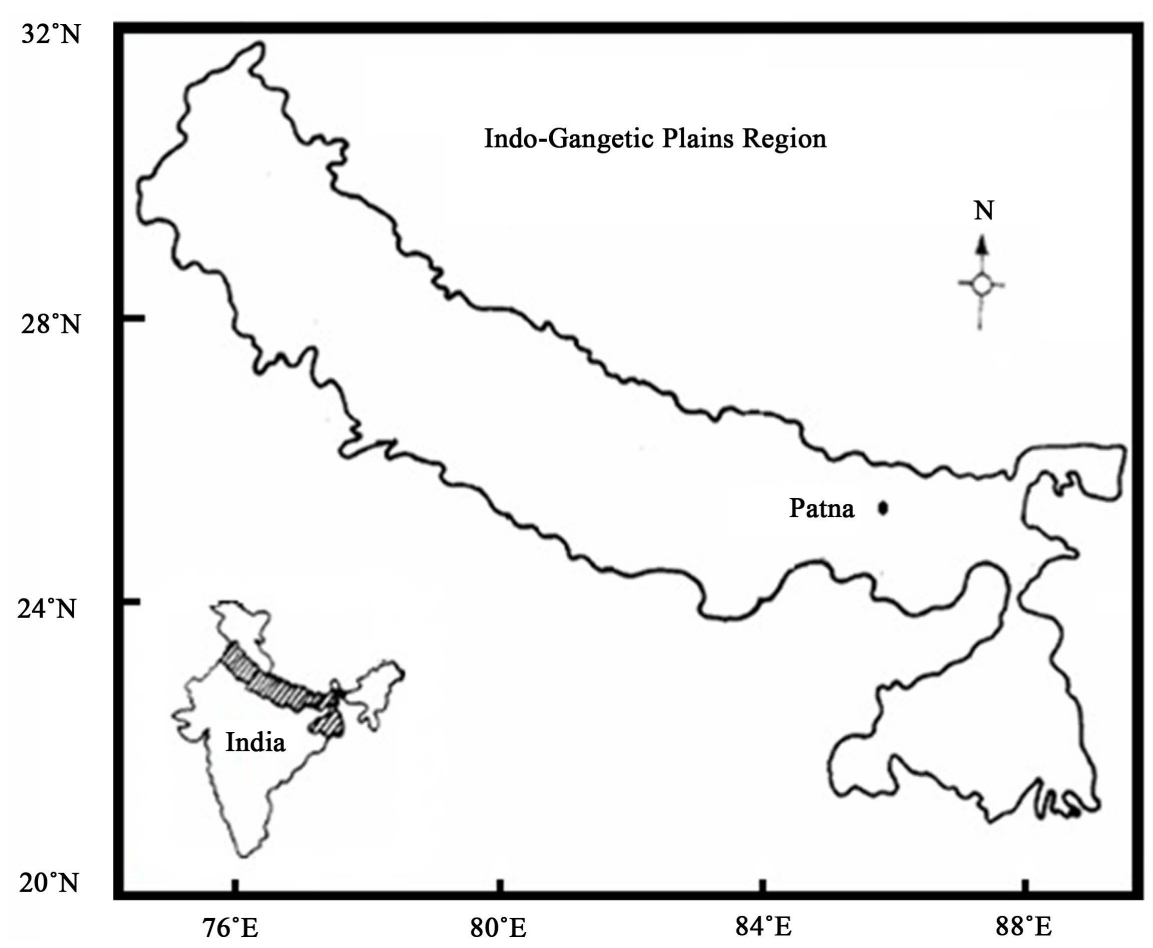

Figure 1. Map of Indo-Gangetic plains. Lifted index and K index for Patna station. 


\section{Results and Discussions}

\subsection{Spatial Variations of Flash Rate Density over the Indo-Gangetic Plains}

Figure 2 shows the spatial variation of flash rate density over the IGP region during the period of study. The spatial variation shows that the maximum flash rate density is recorded over the northern region of IGP $\left(40 \mathrm{fl} \cdot \mathrm{km}^{-2} \cdot \mathrm{yr}^{-1}\right)$ to that of eastern IGP region. Thunderstorms followed by lightning are very frequent during the pre-monsoon season (March, April, and May) over central, east and northwest India and adjoining Bangladesh. During pre-monsoon season a westerly jet stream lies south of the Tibetan Plateau at upper levels while there is ascent over the Indian land mass and descent over the surrounding seas [28]. Anstrong solar heating at the lower levels, resulting in a large-scale circulation with inflow of warm moist air from the Bay of Bengal (BoB) takes place across the eastern coast, depth of which is about $500 \mathrm{~m}$ as detected at an inland station, at about $80 \mathrm{~km}$ from $\mathrm{BoB}$ [29] [30]. Hence the air in the south eastern part is humid and moist while it is relatively dry and cold in the northwestern part, forming the dry line which has a significant role in the formation of severe thunderstorm activity.

During the monsoon, Madden Julian Oscillation (MJO) is largest element of the intra-seasonal (30 - 90 days) variability in the tropical atmosphere. The monsoon trough of low pressure at surface runs from the head of the BoB in the east to Ganganagar in the northwest India and is a semi-permanent feature of the monsoon circulation. The monsoon trough favors the formation of thun-

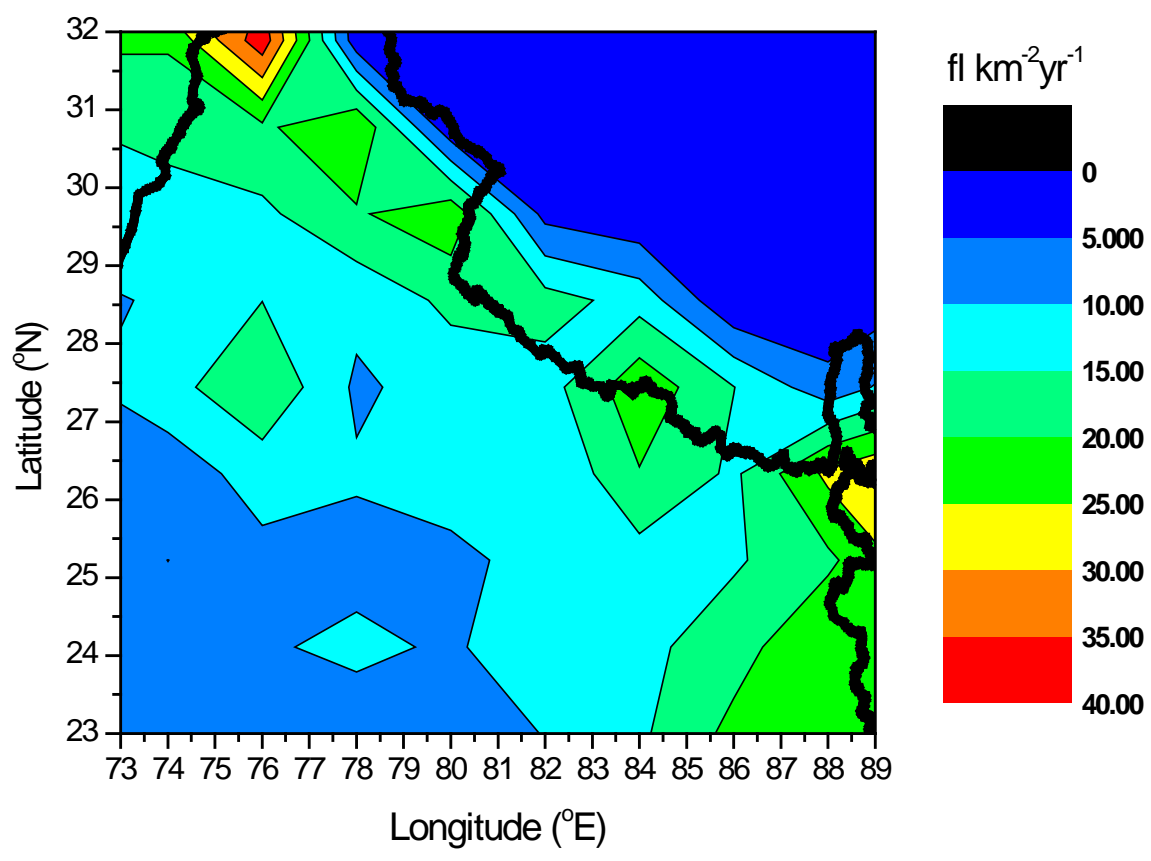

Figure 2. Spatial variation of average flash rate density over the Indo-Gangetic plains during the period 1998-2007. 
derstorms and lightning in the north. When the oscillating MJO comes over the northern most regions that are over the location of the monsoon trough, it produces maximum thunderstorm activity. The landmass distribution and northward movement of the MJO contribute to increasing flash rate density with the latitude. The maximum activity observed over the north India as seen in Figure 2 may be due to formation of thunderstorms due to retreating ITCZ and synoptic scale systems [31]. When ITCZ approaches the equator from its northernmost convection associated with the large-scale circulation dominates over the landmass and orography distribution which produces a bimodal type of variation as seen in Figure 3.

\subsection{Annual Variation of Flash Rate Density and Rainfall Rate over Indo-Gangetic Plains}

Figure 3 and Figure 4 shows annual variation of average FRD and precipitation rate $(\mathrm{mm} /$ day). From these figures, it is seen that during the annual course, the curve for lightning activity show bimodality and rainfall activity exhibit a peak. The FRD shows a consistent increase from February that attains a maximum in May and thereafter it starts decreasing consistently till the end of August and again increases to a second lower peak in September. Pre-monsoon monthly (March-May) convective instability is shown in Figure 5(a) and correlation of air temperature (at $700 \mathrm{mb}$ ) with FRD is shown in Figure 5(b). FRD peaked in pre-monsoon before the rainfall peak (monsoon) as seen in Figure 3. This is attributed to environmental lapse rates $\left(>7.0^{\circ} \mathrm{C} / \mathrm{km}\right)$ during pre-monsoon and al-

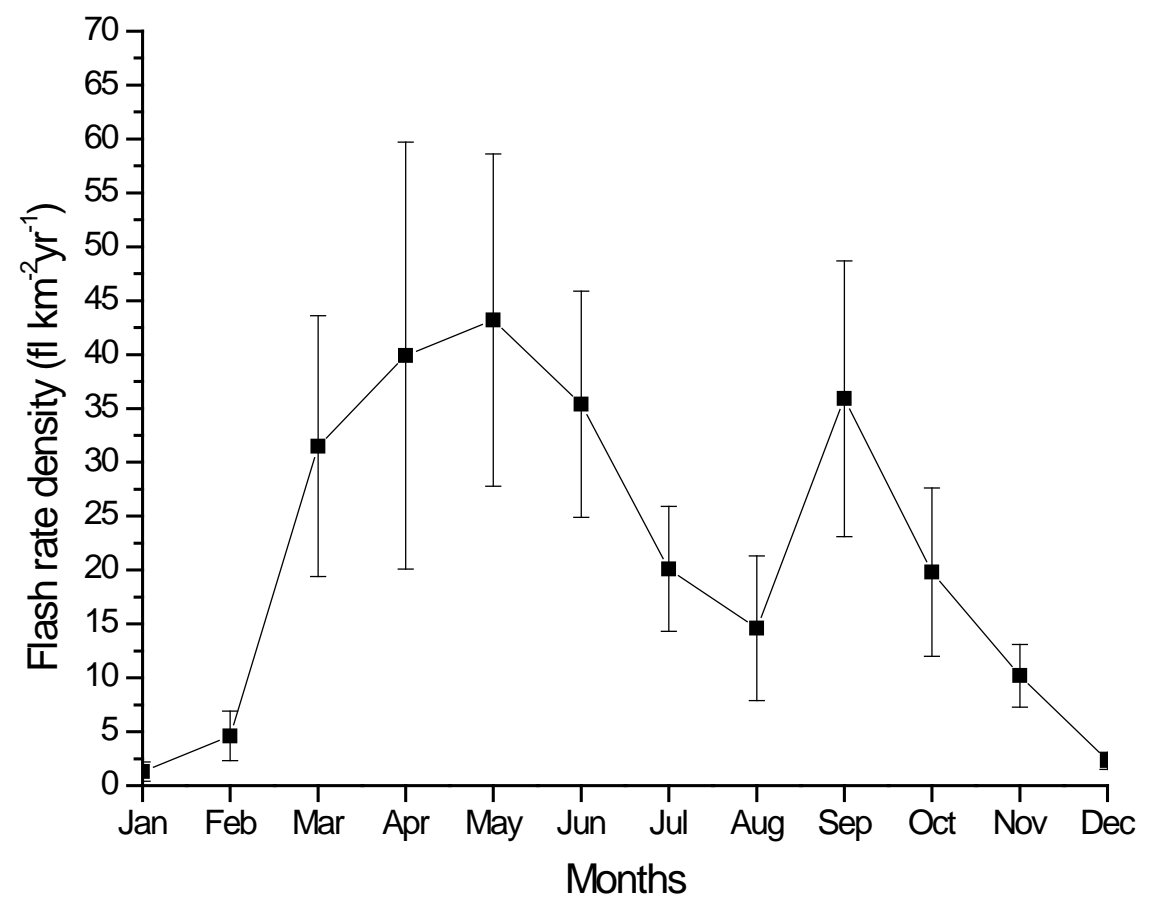

Figure 3. Annual variation of average flash rate density over the Indo-Gangetic plains during the period (1998-2007). 


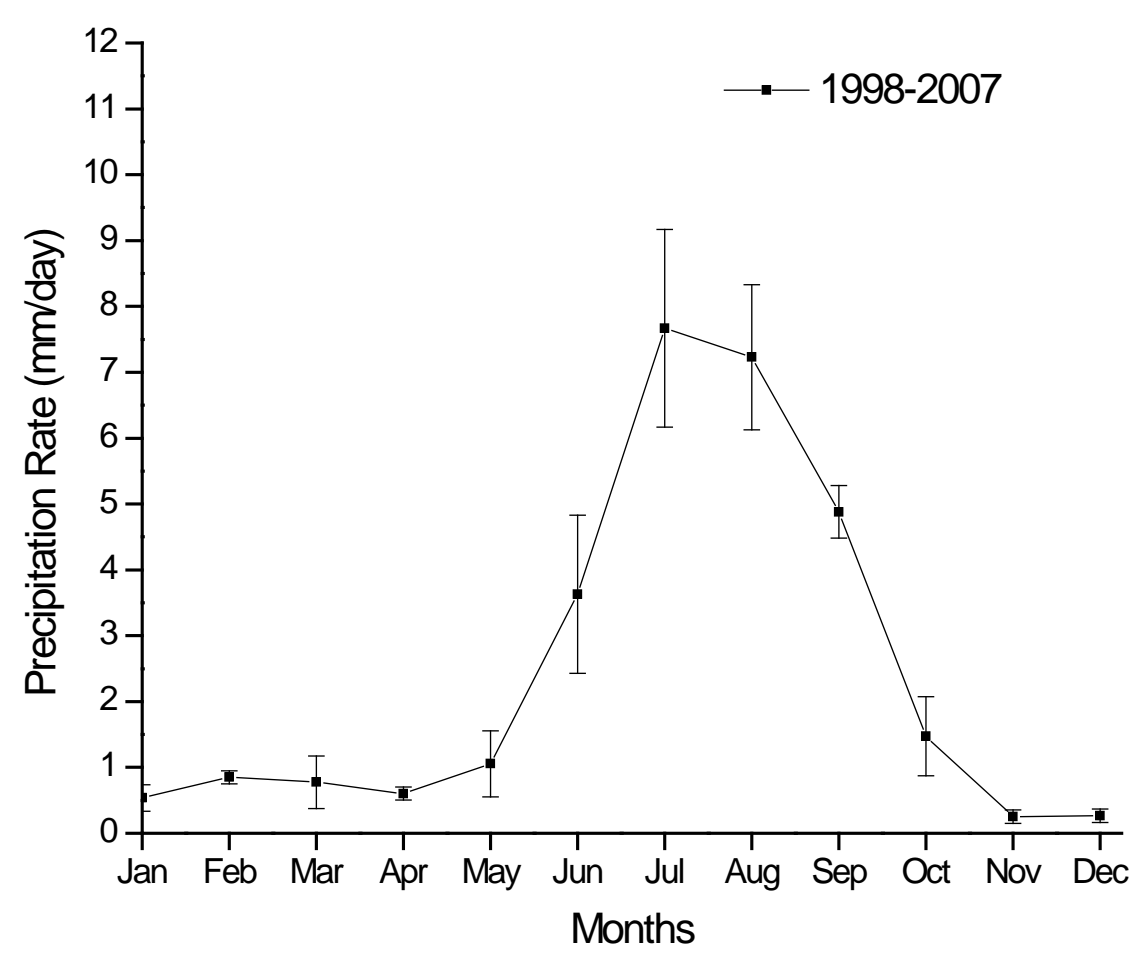

Figure 4. Annual variation of average rainfall rate over the Indo-Gangetic plains during the period (1998-2007).

so, evident from the altitudinal air temperature variation analysis (Figure 5(a)) and a high correlation $(\mathrm{R}=0.70, p \leq 0.0001)$ of air temperature (at $700 \mathrm{mb})$ with FRD during pre-monsoon (Figure $5(\mathrm{~b})$ ).

The bimodality of lightning activity is related to the variation in air temperature in the tropics. Variations in the incoming shortwave radiation from the Sun are attributed [32] to be ultimately responsible for variations in global meteorological parameters on the seasonal timescale. The rainfall activity also shows a similar increase where steep increase is in April and reaches its maximum in July, and then it shows decrease and reaches to its minimum in November. This observed peak of rainfall activity is the significant climatological feature pattern

of the monsoon rainfall and it is the difference between the ascending and descending phase (onset and withdrawal phase) of the monsoon [33]. The onset of the monsoon in early June is followed by the progressive increase in rainfall over the entire country. This phase attains its maximum in the month of July [17]. A careful examination of this figure suggests that there is a lag of nearly 2 months in the occurrence of peaks in lightning and rainfall activity. The plausible explanation for this lag is given below:

Prior to the onset phase of the monsoon, the Indian land mass region experiences maximum convective instability caused by insolation [18] [34]. Hence the overlying boundary layer becomes more strongly buoyant in relation to its surroundings. The larger cloud buoyancy leads to the stronger continental up- 


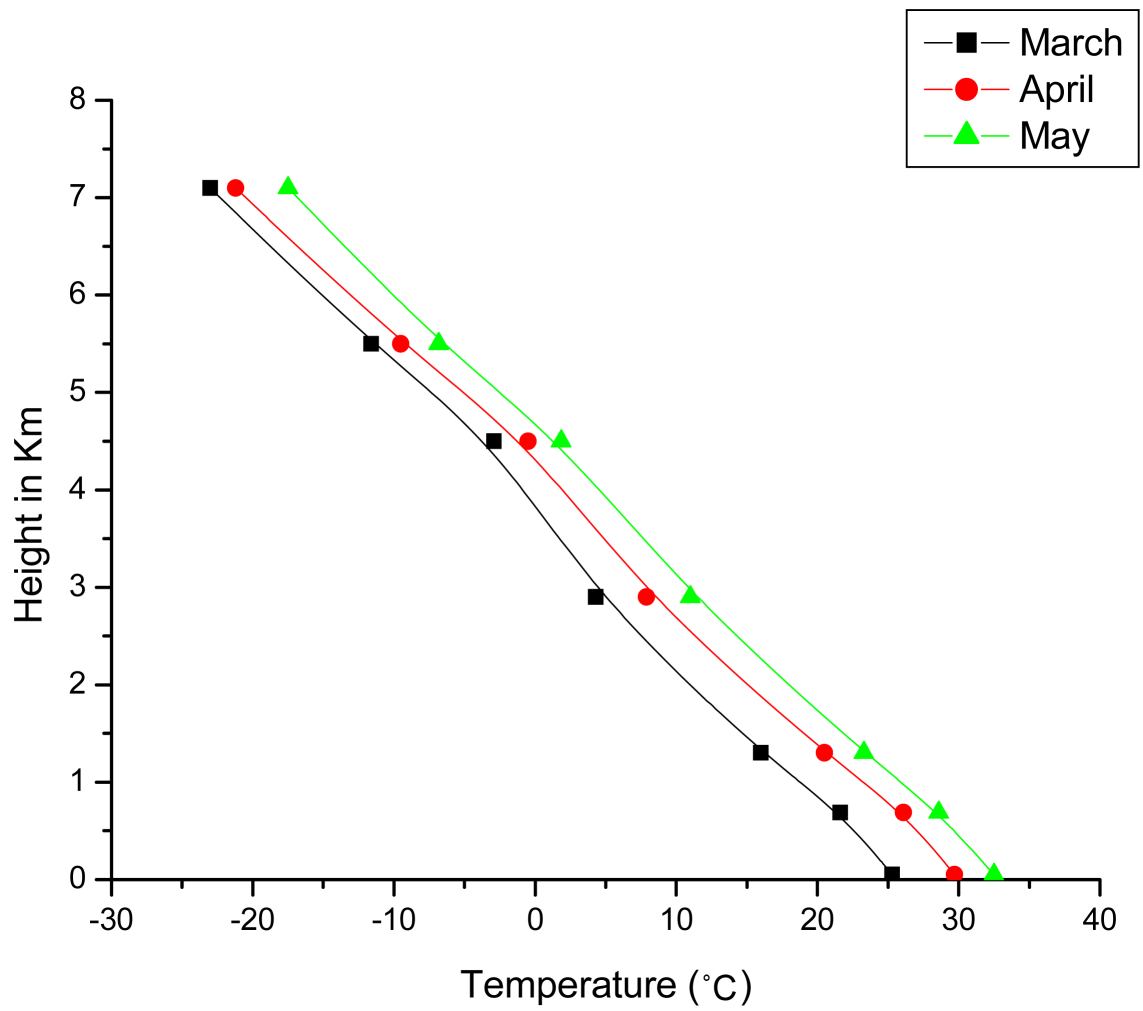

(a)

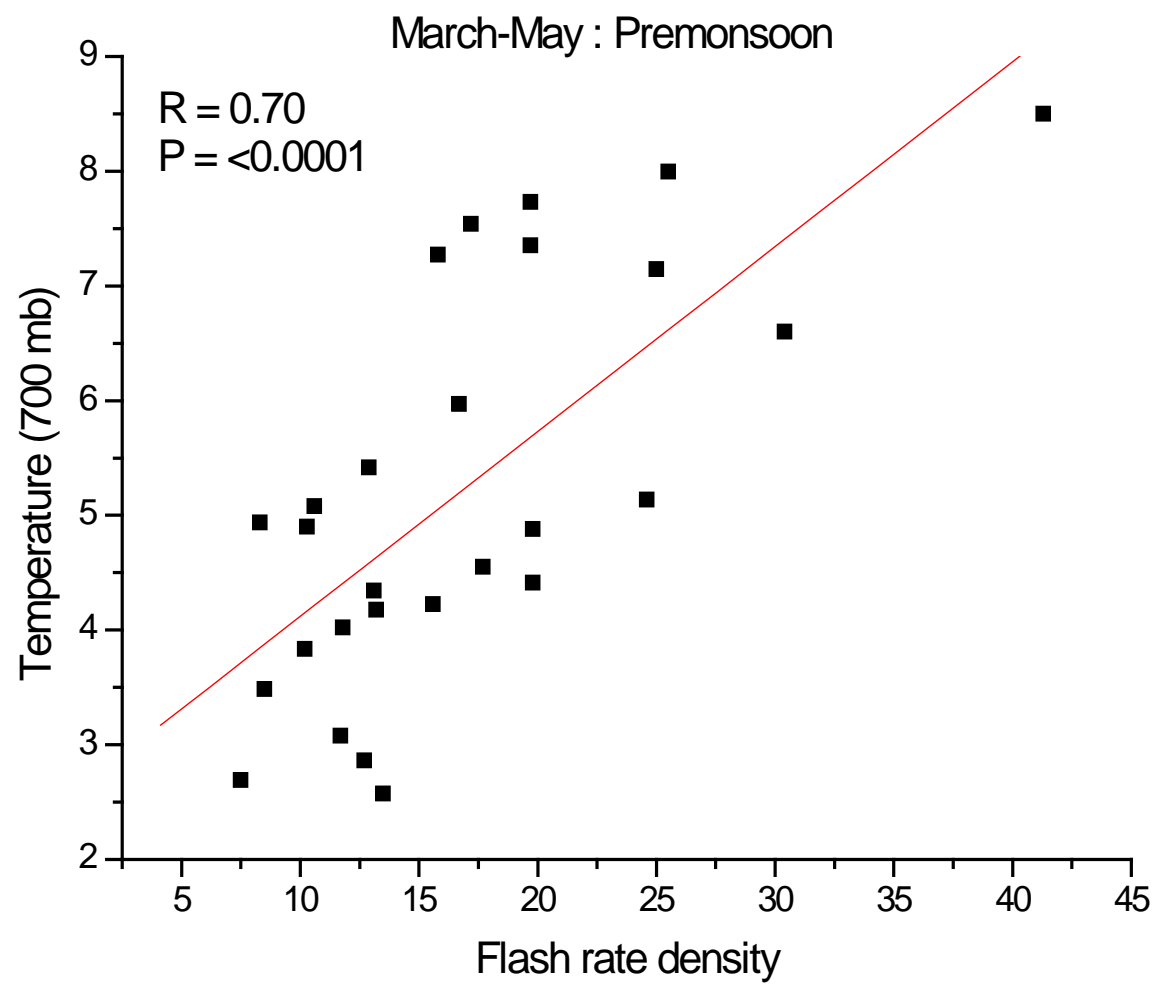

(b)

Figure 5. (a) Variation of air temperature with height in $\mathrm{km}$; (b) Scatter plot of flash rate density and air temperature at $700 \mathrm{mb}$ level for 10 year period (1998-2007). 
drafts, which favors charge separation and lightning [34] [35] [36] [37]. [17] made a study of the electrical properties of large number of deep convective thunderstorms that occurred over the Pune region through the measurement of point discharge current and electric field. Their studies revealed that the high values of electric field and point discharge current in the pre-monsoon season is an indication of the electrically active state of the thundercloud, under such conditions the cloud region electric field is usually intense to cause dielectric breakdown of the atmosphere and thus trigger lightning. Electrified thunderclouds are usually occurs at the end of April and throughout the May. The frequency of occurrence thunderclouds gradually reduces in the first week of June indicating the advancement of the monsoonal rainfall (Figure 3).

It is seen from Figure 6 that the negative LI is seen over March to September. The air is unstable and suggests the possibility of convection. LI are indicators of occurrence of thunderstorms. This is because air parcel rising is much warmer than its surroundings which can accelerate rapidly and create severe thunderstorms. There was sufficient moisture in the atmosphere which leads to an increase in the number of thunderstorm clouds [7] [8] [38] [39]. The value of $\mathrm{K}$ Index lower than $15^{\circ} \mathrm{C}$ [9] indicate very small likelihood of thunderstorms, while $\mathrm{K}$ Index values higher than $35^{\circ} \mathrm{C}$ indicate high probability for the development of numerous and/or severe thunderstorms (as seen in Figure 7). The intense conditional instability over the region develops mixed phase clouds (water + ice) which subsequently produce the lightning activity.

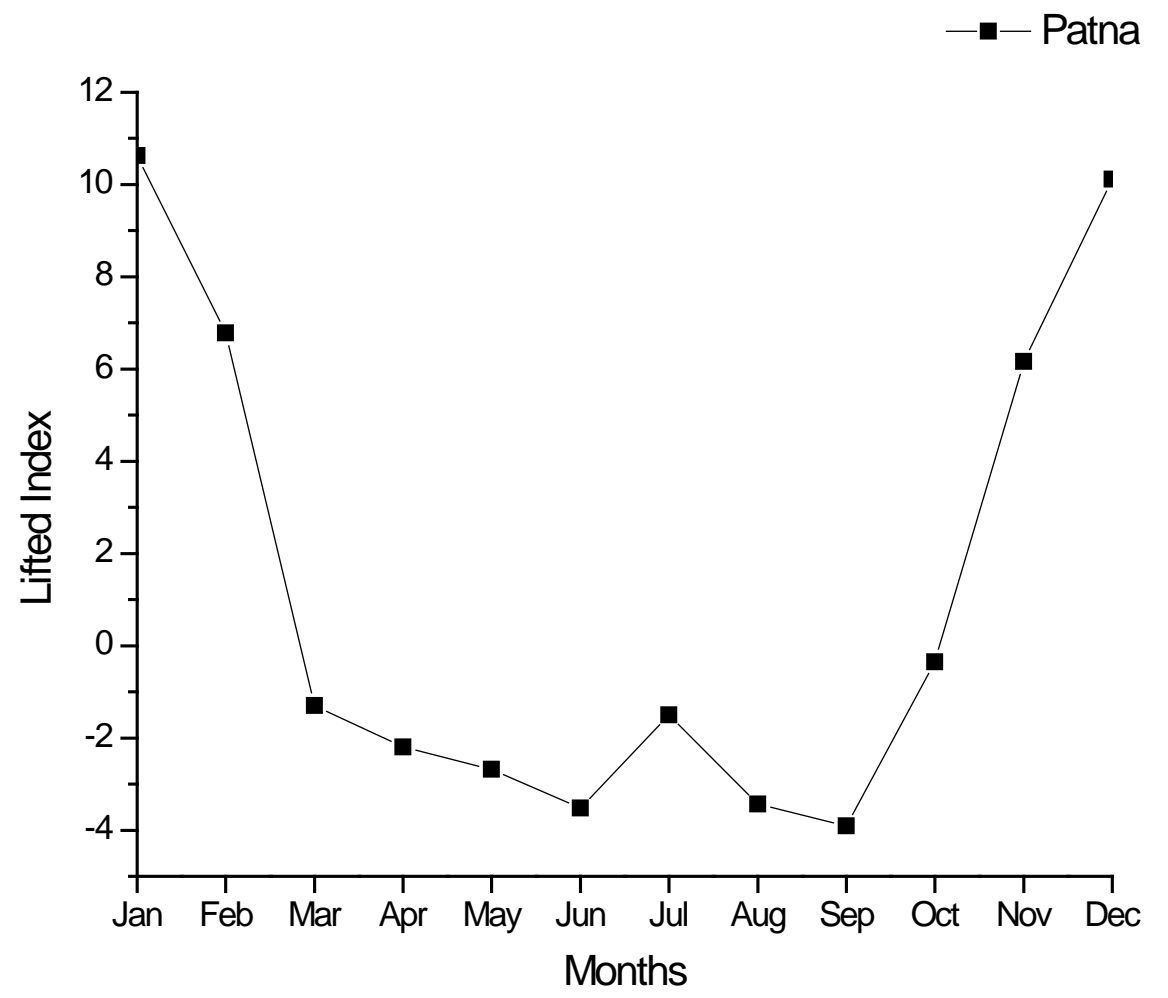

Figure 6. Annual variation of lifted index over Patna station for 10 year period. 


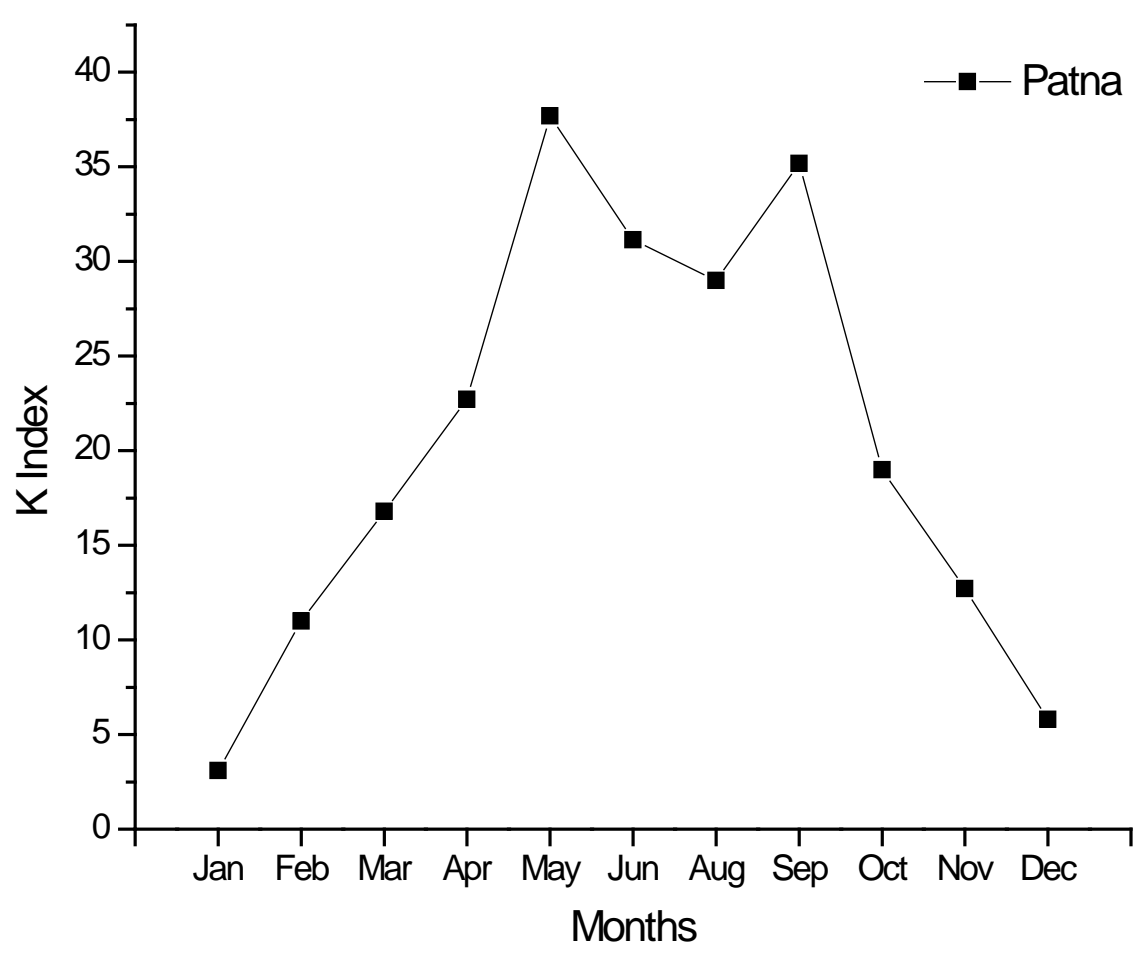

Figure 7. Annual variation of K-index over Patna station for 10 year period.

\section{Conclusions}

The paper presents the association of rainfall and stability index with lightning activity over Indo-Gangatic plain (IGP) region. The results indicate the following concluding remarks.

1) The spatial variation of flash rate density (FRD) and AOD is found to be higher by $40 \mathrm{fl} \cdot \mathrm{km}^{-2} \cdot \mathrm{yr}^{-1}$ over the northern region of IGP to that of eastern IGP region.

2) The annual variation of FRD exhibits bimodal distributions and the precipitation rate shows only one peak in its distributions. The time-lag of 2 months in the peak occurrence of FRD and rainfall rate may be attributed to the environmental lapse rates of more than $7.0^{\circ} \mathrm{C} / \mathrm{km}$ (thunderstorm condition) during premonsoon as is evident from the temperature profiles. Also, high correlation $(\mathrm{R}=$ $0.70, p=<0.0001$ ) of air temperature (at $700 \mathrm{mb}$ ) and $\mathrm{FRD}$ during pre-monsoon support this hypothesis.

3) The annual variation in LI distribution shows negative value from MarchSeptember and also, K-index during pre-monsoon and withdrawal phase of monsoon is due to intense insolation, availability of moisture and on account of large CAPE. The intense conditional instability over the region develops mixed phase clouds (water + ice) which subsequently produce the lightning activity.

4) The thermal heating diminishes on account of monsoonal rainfall and revival of monsoon rain even after break period, the LI is not strong enough to lift the moisture above freezing level. These warm clouds are maritime clouds with intermediate height, moderate updraft and less cloud electrification and hence 
minimum lightning activity in the monsoon season.

\section{Acknowledgements}

The Indian Institute of Tropical Meteorology (IITM), Pune is supported by the Ministry of Earth Sciences (MoES), Government of India, New Delhi. The authors are thankful to Professor Ravi S. Nanjundiah, Director of IITM, Pune, for his kind support and valuable guidance to carry out this research work.

\section{References}

[1] Soriano, L.R., Pablo, F. and Diez, E.G. (2001) Relationship of Precipitation and Cloudto-Ground Lightning in the Iberian Peninsula. Monthly Weather Review, 129, 2998 3003. https://doi.org/10.1175/1520-0493(2001)129<2998:RBCPAC >2.0.CO;2

[2] Ezcurra, A., Areitio, J. and Herrero, I. (2002) Relationships between Cloud to Ground Lightning and Surface Rainfall during 1992-1996 in the Spanish Basque Country Area. Atmospheric Research, 61, 239-250. https://doi.org/10.1016/S0169-8095(01)00133-8

[3] Defer, E., Lagouvardos, K. and Kotroni, V. (2005) Lighting Activity in the Eastern Mediterranean Region. Journal of Geophysical Research, 110, D24210. https://doi.org/10.1029/2004JD005710

[4] Price, C. and Federmesser, B. (2006) Lightning-Rainfall Relationships in Mediterranean Winter Thunderstorms. Geophysical Research Letters, 33, L07813. https://doi.org/10.1029/2005GL024794

[5] Katsanos, D., Lagouvardos, K., Kotroni, V. and Argiriou, A. (2007) Relationship of Lightning Activity with Microwave Brightness Temperatures and Spaceborne Radar Reflectivity Profiles in the Central and Eastern Mediterranean. Journal of Applied Meteorology, 46, 1901-1912. https://doi.org/10.1175/2007JAMC1454.1

[6] Basu, G.C. and Mondal, D.K. (2002) A Forecasting Aspect of Thunder Squall over Calcutta and Its Parameterization, during Pre-Monsoon Season. Mausam, 53, 271 280.

[7] Chaudhari, H.S., Sawaisarje, G.S., Ranalkar, M.R. and Sen, P.N. (2010) Thunderstorms over a Tropical Indian Station, Minicoy: Role of Vertical Wind Shear. Journal of Earth System Science, 119, 603-615. https://doi.org/10.1007/s12040-010-0044-3

[8] Litta, A.J., Idicula, S.M., Mohanty, U.C. and Prasad, S.K. (2012) Comparison of Thunderstorms from WRF-NMM and WRF-ARW Models over East Indian Region. Scientific World Journal, 2012, Article ID: 951870.

https://doi.org/10.1100/2012/951870

[9] Chakraborty, R., Saha, U., Singh, A.K. and Maitra, A. (2017) Association of Atmospheric Pollution and Instability Indices: A Detailed Investigation over an Indian Urban Metropolis. Atmospheric Research, 196, 83-96. https://doi.org/10.1016/j.atmosres.2017.04.033

[10] Balogun, E.E. (1981) Seasonal and Spatial Variation of Thunderstorm Activity over Nigeria. Weather, 36, 192-197. https://doi.org/10.1002/j.1477-8696.1981.tb05398.x

[11] Oladipo, E.O. and Mornu, M.E. (1985) Characteristics of Thunderstorms in Zaria, Nigeria. Weather, 40, 316-322. https://doi.org/10.1002/j.1477-8696.1985.tb03720.x

[12] Prasad, S.K. and Pawar, B.C. (1985) Climatological Studies of Thunderstorm to the West and East of the Western Ghats in the State of Maharashtra and Goa: Part I. Mausam, 4, 107. 
[13] Sivaramkrishnan, T.R. (1990) An Analytical Study of Thunderstorm over Sriharikota. Mausam, 41, 489-491.

[14] Price, C. and Rind, D. (1994) Modeling and Global Lightning Distributions in a General Circulation Model. Monthly Weather Review, 122, 1930-1939. https://doi.org/10.1175/1520-0493(1994)122<1930:MGLDIA>2.0.CO;2

[15] Moid, S.A. (1995) A Climatological Study of Thunderstorms at Mohanbari Airport. Mausam, 46, 202-204.

[16] Williams, E.R., Chan, T. and Boccippio, D.J. (2004) Islands as Miniature Continents: Another Look at the Land-Ocean Lightning Contrast. Journal of Geophysical Research, 109, D16206. https://doi.org/10.1029/2003JD003833

[17] Manohar, G.K., Kandalgaonkar, S.S. and Tinmaker, M.I.R. (1999) Thunderstorm Activity over India and the Indian Southwest Monsoon. Journal of Geophysical Research, 104, 4169-4188. https://doi.org/10.1029/98JD02592

[18] Kandalgaonkar, S.S., Tinmaker, M.I.R., Kulkarni, J.R., Nath, A. and Kulkarni, M.K. (2005) Spatio-Temporal Variability of Lightning Activity over the Indian Region. Journal of Geophysical Research, 110, D11108. https://doi.org/10.1029/2004JD005631

[19] Kandalgaonkar, S.S., Tinmaker, M.I.R., Nath, A.S., Kulkarni, M.K. and Trimbake, H.K. (2005) Study of Thunderstorm and Rainfall Activity over the Indian Region. Atmosfera, 18, 91-101.

[20] Manohar, G.K. and Kesarkar, A.P. (2005) Climatology of Thunderstorm Activity over the Indian Region: III. Latitudinal and Seasonal Variation. Mausam, 56, 581592.

[21] Tinmaker, M.I.R., Aslam, M.Y., Ghude, S.D. and Chate, D.M. (2016) Lightning Activity with Rainfall during El Nino and La Nina Events over India. Theoretical and Applied Climatology, 1-10. https://doi.org/10.1007/s00704-016-1883-x

[22] Chate, D.M., Tinmaker, M.I.R., Aslam, M.Y. and Ghude, S.D. (2017) Climate Indicators for Lightning over Sea, Sea-Land Mixed and Land-Only Surfaces in India. International Journal of Climatology, 37, 1672-1679.

https://doi.org/10.1002/joc.4802

[23] Christian, H.J., et al. (1999) Global Frequency and Distribution of Lightning as Observed by the Optical Transient Detector (OTD). 11 th International Conference on Atmospheric Electricity, Guntersville, 7-11 June 1999, 726-729.

[24] Bond, D.W., Steiger, S., Zhang, R., Tie, X. and Orville, R.E. (2002) The Importance of $\mathrm{NO}_{\mathrm{x}}$ Production by Lightning in the Tropics. Atmospheric Environment, 36, 1509-1519. https://doi.org/10.1016/S1352-2310(01)00553-2

[25] Cecil, D.J., Buechler, D.E. and Blakeslee, R.J. (2014) Gridded Lightning Climatology from TRMM-LIS and OTD: Dataset Description. Atmospheric Research, 135-136, 404-414. https://doi.org/10.1016/j.atmosres.2012.06.028

[26] Boccippio, D.J., Goodman, S.J. and Heckman, S. (2000) Regional Differences in Tropical Lightning Distribution. Journal of Applied Meteorology, 39, 2231-2248. https://doi.org/10.1175/1520-0450(2001)040<2231:RDITLD>2.0.CO;2

[27] Albrecht, R.I., Goodman S.J., Petersen W.A., Buechler, D.E., Bruning E.C., Blakeslee R.J. and Christian, H.J. (2011) The 13 Years of TRMM Lightning Imaging Sensor: From Individual Flash Characteristics to Decadal Tendencies. 14th International Conference on Atmospheric Electricity, Rio de Janeiro, 8-12 August 2011, 1-4.

[28] Weston, K.J. (1972) The Dry Line of Northern Indian and Its Role in Cumulonim- 
bus Convection. Quarterly Journal of the Royal Meteorological Society, 98, 519-532. https://doi.org/10.1002/qj.49709841704

[29] Lohar, D., Pal, B. and Chakravarty, B. (1994) Sea Breeze Activity at an Inland Station Kharagpur (India)_A Case Study. Boundary Layer Meteorology, 67, 427-434. https://doi.org/10.1007/BF00705442

[30] Sadhukhan, I. and De, U.K. (1998) Pre-Monsoon and Convective Development over Gangetic West Bengal during 1980-1989. International Journal of Radio and Space Physics, 27, 102-109.

[31] Sikka, D.R. and Gadgil, S. (1980) On the Maximum Cloud Zone and the ITCZ over Indian Longitude during Southwest Monsoon. Monthly Weather Review, 108, 1840 1853. https://doi.org/10.1175/1520-0493(1980)108<1840:OTMCZA >2.0.CO;2

[32] Williams, E.R. (1994) Global Circuit Response to Seasonal Variations in Global Surface Air Temperature. Monthly Weather Review, 172, 1917-1929. https://doi.org/10.1175/1520-0493(1994)122<1917:GCRTSV>2.0.CO;2

[33] Ananthakrishnan, R. and Pathan, J.M. (1991) A Climatological Singularity around Mid-August in the Summer Monsoon Rainfall of India. Current Science, 60, 439445.

[34] Williams, E.R., et al. (2002) Contrasting Convective Regimes over the Amazon: Implications for Cloud Electrification. Journal of Geophysical Research, 107, 8082. https://doi.org/10.1029/2001JD000380

[35] Rutledge, S.A., Williams, E.R. and Keenan, T.D. (1992) The Down under Doppler and Electricity Experiment (DUNDEE): Overview and Preliminary Results. Bulletin of the American Meteorological Society, 73, 3-16. https://doi.org/10.1175/1520-0477(1992)073<0003:TDUDAE >2.0.CO;2

[36] Halverson, J., Rickenbach, T., Roy, B., Pierce, H. and Williams, E.R. (2002) Environmental Characteristics of Convective Systems during TRMM-LBA. Monthly Weather Review, 130, 1493-1509. https://doi.org/10.1175/1520-0493(2002)130<1493:ECOCSD>2.0.CO;2

[37] Cifelli, R., Petersen, W.A., Carey, L.D. and Rutledge, S.A. (2002) Radar Observations of the Kinematic Microphysical and Precipitation Characteristics of Two MCSs in TRMM LBA. Journal of Geophysical Research, 107, 1-44. https://doi.org/10.1029/2000JD000264

[38] Galway, J.G. (1956) The Lifted Index as a Predictor of Latent Instability. Bulletin of the American Meteorological Society, 37, 528-529.

[39] Schulz, P. (1989) Relationships of Several Stability Indices to Convective Weather Events in Northeast Colorado. Weather Forecasting, 4, 73-80. https://doi.org/10.1175/1520-0434(1989)004<0073:ROSSIT>2.0.CO;2 
Submit or recommend next manuscript to SCIRP and we will provide best service for you:

Accepting pre-submission inquiries through Email, Facebook, LinkedIn, Twitter, etc. A wide selection of journals (inclusive of 9 subjects, more than 200 journals)

Providing 24-hour high-quality service

User-friendly online submission system

Fair and swift peer-review system

Efficient typesetting and proofreading procedure

Display of the result of downloads and visits, as well as the number of cited articles Maximum dissemination of your research work

Submit your manuscript at: http://papersubmission.scirp.org/

Or contact ajcc@scirp.org 